\title{
Diversification of ${ }^{99} \mathrm{Mo} /{ }^{99} \mathrm{~m}$ Tc Separation: Non-Fission Reactor Production of ${ }^{99} \mathrm{Mo}$ as a Strategy for Enhancing ${ }^{99 m}$ Tc Availability
}

\author{
Maroor R.A. Pillai ${ }^{1}$, Ashutosh Dash ${ }^{2}$, and Furn F. (Russ) Knapp, Jr. $^{3}$ \\ ${ }^{I}$ Molecular Group of Companies, Cochin, India; ${ }^{2}$ Isotope Production and Applications Division, Bhabha Atomic Research Centre \\ (BARC), Mumbai, India; and ${ }^{3}$ Medical Radioisotope Program, Oak Ridge National Laboratory (ORNL), Oak Ridge, Tennessee
}

This paper discusses the benefits of obtaining ${ }^{99 m} T \mathrm{c}$ from non-fission reactor-produced low-specific-activity ${ }^{99} \mathrm{Mo}$. This scenario is based on establishing a diversified chain of facilities for the distribution of ${ }^{99 m}$ Tc separated from reactor-produced ${ }^{99} \mathrm{Mo}$ by $(n, y)$ activation of natural or enriched Mo. Such facilities have expected lower investments than required for the proposed chain of cyclotrons for the production of $99 \mathrm{mT}$. Facilities can receive and process reactorirradiated Mo targets then used for extraction of ${ }^{99 \mathrm{mT}} \mathrm{Tc}$ over a period of $2 \mathrm{wk}$, with 3 extractions on the same day. Estimates suggest that a center receiving $1.85 \mathrm{TBq}(50 \mathrm{Ci})$ of ${ }^{99} \mathrm{Mo}$ once every $4 \mathrm{~d}$ can provide 1.48-3.33 TBq $(40-90 \mathrm{Ci})$ of $99 \mathrm{mTc}$ daily. This model can use research reactors operating in the United States to supply current ${ }^{99}$ Mo needs by applying natural nat Mo targets. ${ }^{99}$ Mo production capacity can be enhanced by using ${ }^{98} \mathrm{Mo}$-enriched targets. The proposed model reduces the loss of ${ }^{99} \mathrm{Mo}$ by decay and avoids proliferation as well as waste management issues associated with fission-produced ${ }^{99} \mathrm{Mo}$.

Key Words: ${ }^{99} \mathrm{Mo}$; ${ }^{99 \mathrm{mT}}$; fission moly; reactor production; cyclotron production

J Nucl Med 2015; 56:159-161

DOI: 10.2967/jnumed.114.149609

\section{$\mathbf{S}$}

options are under consideration to ensure the uninterrupted supply of ${ }^{99 m}$ Tc for nuclear medicine applications (1-3). A recent article suggested the potential advantages of a diversified production approach using medium-energy cyclotrons to enhance ${ }^{99 \mathrm{~m}} \mathrm{Tc}$ availability (4). Highly enriched ${ }^{100} \mathrm{Mo}$ targets are irradiated with 18- to $25-\mathrm{MeV}$ protons to yield ${ }^{99 \mathrm{~m}} \mathrm{Tc}\left[{ }^{100} \mathrm{Mo}(\mathrm{p}, 2 \mathrm{n})^{99 \mathrm{~m}} \mathrm{Tc}\right]$. As an example, a $1.5-\mathrm{g}{ }^{100} \mathrm{Mo}$ solid target irradiated with $18-\mathrm{MeV}$ protons at $240-\mu \mathrm{A}$ beam current for $6 \mathrm{~h}$ can provide about $333 \mathrm{GBq}$ (9 Ci) of ${ }^{99} \mathrm{~m} \mathrm{Tc}$ at end of bombardment (EOB) (5). The possibility of such a strategy will depend on daily irradiation of ${ }^{100} \mathrm{Mo}$ targets and radiochemical processing to recover ${ }^{99} \mathrm{~m}$ Tc as pertechnetate solution before distribution (Fig. 1). A large network of new cyclotron facilities having compliance with title 21 of Code of Federal Regulations

Received Oct. 24, 2014; revision accepted Dec. 4, 2014.

For correspondence contact: Furn F. (Russ) Knapp, Mail Stop 6229, Building 4501, Oak Ridge National Laboratory (ORNL), P.O. Box 2008, 1 Bethel Valley Rd., Oak Ridge, TN 27830-6229.

E-mail: knappffir@ornl.gov

Published online Dec. 23, 2014.

COPYRIGHT (C) 2015 by the Society of Nuclear Medicine and Molecular Imaging, Inc. part 212 or U.S. Pharmacopeia $<823>$ for ${ }^{99 \mathrm{~m}} \mathrm{Tc}$ production similar to existing PET radiopharmaceutical production facilities would be needed for the success of this model.

In this communication, we propose a similar scheme of diversified radiochemical processing facilities for reactor-produced low-specific-activity ${ }^{99} \mathrm{Mo}$ for the preparation of ${ }^{99 \mathrm{~m}} \mathrm{Tc}$-pertechnetate (6). The distinct advantage of this strategy is based on optimal use of reactor-produced ${ }^{99} \mathrm{Mo}$ by minimizing decay loss. It is estimated that, currently, approximately $60 \%-80 \%$ of ${ }^{99} \mathrm{Mo}$ is lost from radioactive decay before facility receipt of ${ }^{99} \mathrm{Mo} /{ }^{99 \mathrm{~m}} \mathrm{Tc}$ generators (7). We estimate that by using only 1 or 2 of the existing U.S. nuclear reactors, our model could provide sufficient ${ }^{99 \mathrm{~m}} \mathrm{Tc}$ to meet the entire U.S. requirement for ${ }^{99 \mathrm{~m}} \mathrm{Tc}$ (Fig. 2).

\section{HOW MUCH ${ }^{99 m}$ TC IS REQUIRED?}

Approximately 50,000 diagnostic procedures are estimated to be performed with ${ }^{99 \mathrm{~m}} \mathrm{Tc}$ radiopharmaceuticals in the United States daily (3). Patient doses vary from a few hundred megabecquerels to a maximum of $1.1 \mathrm{GBq}$. The daily activity levels of ${ }^{99 \mathrm{~m}} \mathrm{Tc}$ administered to all patients in the United States can be as high as $55.5 \mathrm{TBq}$ $(1,500 \mathrm{Ci})$. The total available ${ }^{99 \mathrm{~m}} \mathrm{Tc}$ activity is not used because significant activity is lost through radioactive decay, and the actual U.S. ${ }^{99 m}$ Tc activity requirement could be about $111 \mathrm{TBq}$ (3,000 Ci). If the proposed cyclotron route is used as the principal U.S. source of ${ }^{99 \mathrm{~m}} \mathrm{Tc}$, it would be expected that more than 300 distributed cyclotrons may be required, whereas the use of a couple of existing nuclear reactors would be expected to suffice for our alternative strategy.

\section{DIVERSIFIED PROCESSING FACILITIES FOR REACTOR-PRODUCED LOW-SPECIFIC-ACTIVITY ${ }^{99} \mathrm{Mo}$}

The reactor production of ${ }^{99}$ Mo by irradiating natural molybdenum trioxide was used earlier for the preparation of ${ }^{99 \mathrm{~m}} \mathrm{Tc}$ but was mostly abandoned after the introduction and wide availability of the alumina-based ${ }^{99} \mathrm{Mo} /{ }^{99} \mathrm{~m} \mathrm{Tc}$ column generator using fission-produced high-specific-activity ${ }^{99} \mathrm{Mo}$. We propose to revive this earlier accepted technology using a network of geographically diversified radiochemical processing facilities for the separation of ${ }^{99 \mathrm{~m}} \mathrm{Tc}$ from ${ }^{99} \mathrm{Mo}$. The irradiated molybdenum targets can be transported to these radiochemical processing facilities, and the expected transportation time is less than $24 \mathrm{~h}$ either by road or air. As an example, irradiation of $25 \mathrm{~g}$ of a ${ }^{\text {nat }} \mathrm{Mo}$ powder target (i.e., as the oxide; $24.13 \%{ }^{98} \mathrm{Mo}$ ) for $6 \mathrm{~d}$ in a reactor with an approximate flux of $6 \times 10^{14}$ neutrons $/ \mathrm{cm}^{2} / \mathrm{s}$ would result in the production of about $1.85 \mathrm{TBq}(50 \mathrm{Ci})$ of ${ }^{99} \mathrm{Mo}$ at EOB. Assuming a decay loss of about $25 \%$ during transport, 
FIGURE 1. Production of $99 \mathrm{mTC}$ from cyclotron-irradiated ${ }^{100} \mathrm{Mo}$. After irradiation, target is processed by recovering irradiated ${ }^{100}$ Mo from solid target together with ${ }^{99 \mathrm{mT}}$ Tc. ${ }^{99 \mathrm{mT}} \mathrm{Tc}$ is separated and purified to obtain pertechnetate solution for onward transfer to users. Separation process can be performed only once with irradiated targets. Unused ${ }^{100} \mathrm{Mo}$ can be recovered, stored, and reused for further irradiation.

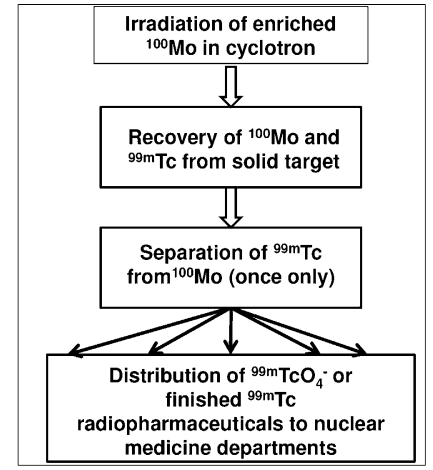

$1.4 \mathrm{TBq}(38 \mathrm{Ci})$ of ${ }^{99} \mathrm{Mo}$ will be available for radiochemical processing. Recovering the irradiated dry powder and simple dissolution in sodium hydroxide solution provides sodium $\left({ }^{99} \mathrm{Mo}\right)$ molybdate, the source of ${ }^{99 \mathrm{~m}} \mathrm{Tc} .{ }^{99 \mathrm{~m}} \mathrm{Tc}$ can be separated using any one of the established methods (8). Solvent extraction using methyl ethyl ketone is effective and simple, and cost-effective automated modules can be developed for the preparation of high concentrations of no-carrier-added ${ }^{99 \mathrm{~m}} \mathrm{Tc}$ activity (9). Alternatively, solid-phase extraction chromatographic separation also can be adapted (10).

Instead of a single ${ }^{99 \mathrm{~m}} \mathrm{Tc}$ extraction from the irradiated target by the cyclotron route, the ${ }^{99 \mathrm{~m}} \mathrm{Tc}$ can be extracted from ${ }^{99} \mathrm{Mo}$ stock solution at frequent intervals-for instance, every $6 \mathrm{~h}$ beginning in the early morning - and transported to users either as pertechnetate or as finished radiopharmaceuticals. The 6-h ${ }^{99 \mathrm{~m} T c}$ half-life allows easy distribution of radiopharmaceutical products. If the ${ }^{99} \mathrm{Mo}$ processing facilities are established in the same location as cyclotron facilities used for ${ }^{18} \mathrm{~F}$ production, the existing ${ }^{18} \mathrm{~F}$-FDG distribution network can be used for ${ }^{99 \mathrm{~m}} \mathrm{Tc}$ products. Figure 3 shows the amount of ${ }^{99 \mathrm{~m}} \mathrm{Tc}$ available from a single batch of $1.85 \mathrm{TBq}(50 \mathrm{Ci})$ of ${ }^{99} \mathrm{Mo}$ at EOB over a period of $12 \mathrm{~d}$, with 3 extractions on the same day at 6-h intervals. About $9.62 \mathrm{TBq}(260 \mathrm{Ci})$ of ${ }^{99 \mathrm{~m}} \mathrm{Tc}$ can be obtained from a single $1.85-\mathrm{TBq}(50-\mathrm{Ci})$ batch of ${ }^{99} \mathrm{Mo}$. This is in contrast to a single separation possible from a cyclotron-irradiated enriched ${ }^{100} \mathrm{Mo}$ target.

An important cost-saving advantage of using reactorproduced low-specific-activity ${ }^{99} \mathrm{Mo}$ is that usable quantities of ${ }^{99 \mathrm{~m}} \mathrm{Tc}$ activity can be repeatedly extracted, for as long as 2 wk. Fresh lots of ${ }^{99}$ Mo could be supplied at 4-d intervals.

FIGURE 2. Production of ${ }^{99 \mathrm{mT}} \mathrm{Tc}$ from reactor-irradiated natMo targets. Irradiated targets are transferred to diversified radiochemical processing facilities. Target is dissolved in $\mathrm{NaOH}$ inside hot cell to obtain $\mathrm{Na}_{2} \mathrm{MoO}_{4}$ solution. Multiple extractions can be performed on same day as well as over period of 12-14 d. Pertechnetate solution is distributed to user departments. Scaling up can be accomplished by using ${ }^{98} \mathrm{Mo}-$ enriched target, which can be recovered for reuse.
Simultaneous operation of 3 batches of ${ }^{99} \mathrm{Mo}$ and multiple daily extractions could manage to produce a sustained supply of ${ }^{99} \mathrm{~m}$ Tc on a daily basis. Figure 4 illustrates the activity levels of ${ }^{99} \mathrm{Mo}$ available on each day and the activity of ${ }^{99 \mathrm{~m}} \mathrm{Tc}$ extractable on a daily basis. If 3 batches of ${ }^{99} \mathrm{Mo}$ are available simultaneously in a processing center, the ${ }^{99 \mathrm{~m}} \mathrm{Tc}$ activity available is expected to vary from 1.48 to $3.33 \mathrm{TBq}(40-90 \mathrm{Ci})$ of ${ }^{99 \mathrm{~m}} \mathrm{Tc}$. In such a scenario, 60 such processing facilities could produce $111 \mathrm{TBq}(3,000 \mathrm{Ci})$ of ${ }^{99 \mathrm{~m}} \mathrm{Tc}$, which is sufficient to conduct 50,000 daily investigations, the estimated current U.S. demand. Depending on the capacity available for irradiation, participation by a limited number of reactors in the United States could thus provide the entire U.S. ${ }^{99 \mathrm{~m}} \mathrm{Tc}$ requirement. Such a ${ }^{99} \mathrm{Mo}$ production scenario can be scaled up by a factor of approximately 4 with enriched ${ }^{98} \mathrm{Mo}$ targets $\left(>95 \%{ }^{98} \mathrm{Mo}\right)$, theoretically yielding up to $444 \mathrm{TBq}(12,000 \mathrm{Ci})$ of ${ }^{99 \mathrm{~m}} \mathrm{Tc}$ daily. Enriched targets can be recovered for reuse, a scenario similar to the recovery and reuse of ${ }^{100} \mathrm{Mo}$ targets in the case of cyclotron production.

\section{INVESTMENT NEEDED AT EACH PROCESSING FACILITY}

Only moderate investment would be expected for each processing facility, with the basic essential requirements being based on the availability of licensed facilities equipped with the required shielding, ventilation, and waste-handling capabilities, which would also include 1 hot cell for processing the irradiated targets and 1 or 2 hot cells for installation of ${ }^{99 \mathrm{~m}} \mathrm{Tc} /{ }^{99} \mathrm{Mo}$ separation systems. Additional investment would be required for installation of automated modules for separation of ${ }^{99 \mathrm{~m}} \mathrm{Tc}$ from ${ }^{99} \mathrm{Mo}$. The facility, as well as the hot cells used for placing the module for separation of ${ }^{99 \mathrm{~m}} \mathrm{Tc}$, must be compliant with good manufacturing practices, since the pertechnetate will be used for the formulation

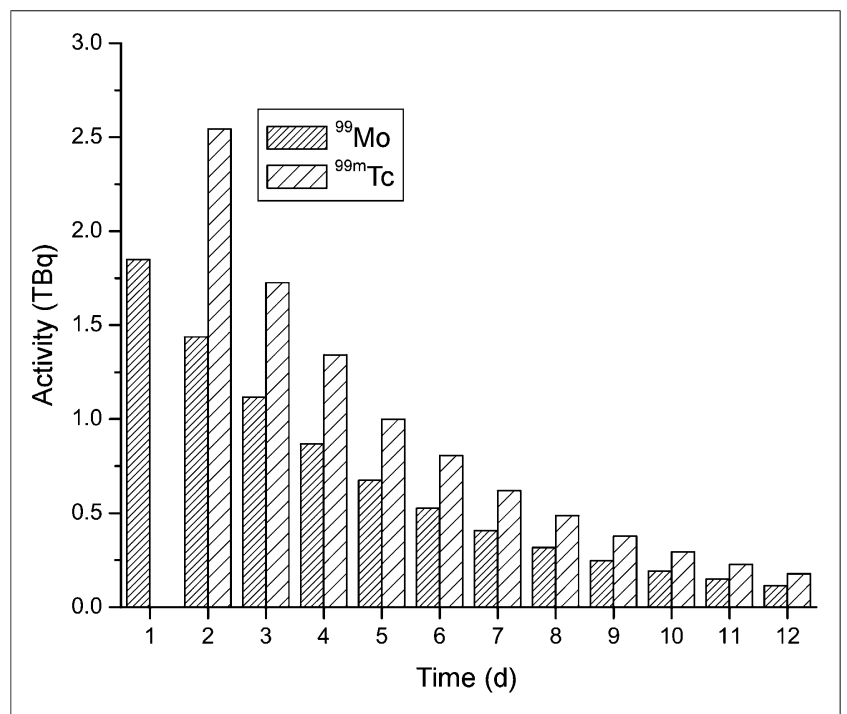

FIGURE 3. Decay of $1.85 \mathrm{TBq}(50 \mathrm{Ci})$ of ${ }^{99} \mathrm{Mo}$ over period of $11 \mathrm{~d}$ and 99mTc available on each day from single batch of $1.85 \mathrm{TBq}(50 \mathrm{Ci})$ of ${ }^{99} \mathrm{Mo}$. ${ }^{99 \mathrm{mTc}}$ is eluted at 3 intervals starting from $400 \mathrm{~h}$ with gap of $6 \mathrm{~h}$. Elution is not shown on day 1 , since this is time required for transport of ${ }^{99} \mathrm{Mo}$ from reactor to processing laboratories. About 9.62 TBq (260 Ci) of ${ }^{99 \mathrm{~m} T c}$ can be recovered from single batch of $1.85 \mathrm{TBq}(50 \mathrm{Ci})$ at EOB of ${ }^{99}$ Mo supplied to processing center. 


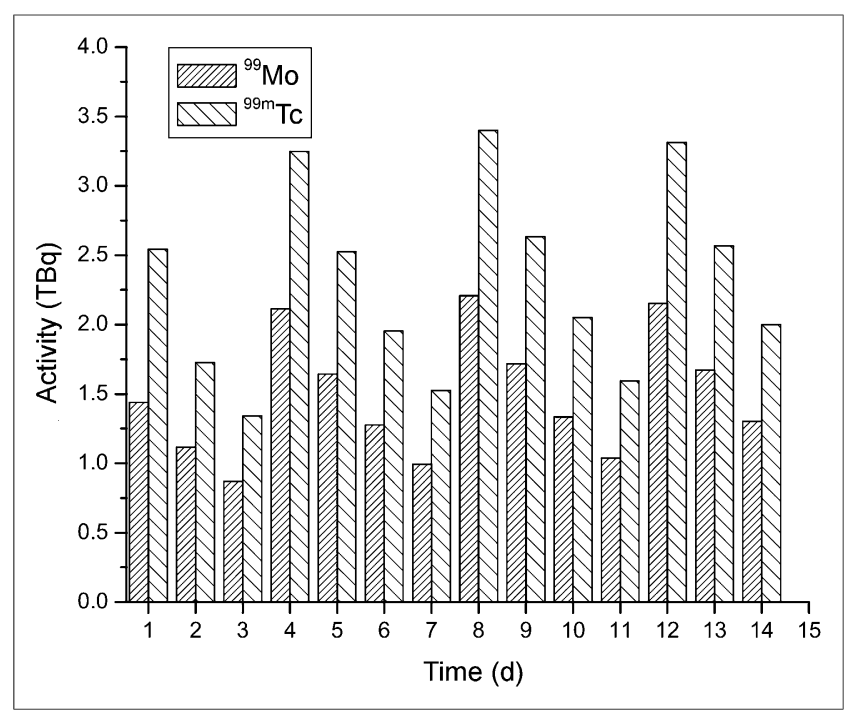

FIGURE 4. ${ }^{99} \mathrm{Mo}$ and ${ }^{99 \mathrm{~m} T c}$ availability in central processing facility when $1.85 \mathrm{TBq}(50 \mathrm{Ci})$ of ${ }^{99} \mathrm{Mo}$ are shipped at interval of $4 \mathrm{~d}$. Assuming 3 elutions, ${ }^{99 \mathrm{mTC}}$ availability at center varies from 1.48 to $3.33 \mathrm{TBq}(40-$ $90 \mathrm{Ci})$ per day after eighth day when 3 batches of ${ }^{99} \mathrm{Mo}$ are simultaneously used.

of radiopharmaceuticals. Facility compliance with title 21 of Code of Federal Regulations parts 210 and 211, and U.S. Pharmacopeia $<797>$, may in fact be expected to be easier with the reactor route than with processing of cyclotron targets, since both methyl ethyl ketone extraction and solid-phase chromatographic procedures have already received Food and Drug Administration approval.

The expected cost for equipment to set up such a facility having 2-3 hot cells together with a couple of automated modules would be in the range of 2-4 million dollars. The production capabilities of each ${ }^{99 \mathrm{~m}} \mathrm{Tc} /{ }^{99} \mathrm{Mo}$ separation unit could be as high as $1.48-1.85$ TBq $(40-50 \mathrm{Ci})$ of ${ }^{99 \mathrm{~m}} \mathrm{Tc}$ per day, which translates to about 555 $\mathrm{TBq}(15,000 \mathrm{Ci})$ of ${ }^{99 \mathrm{~m}} \mathrm{Tc}$ annually, or the equivalent of 500,000 patient doses. In conjunction with existing central radiopharmacies or cyclotron centers, it is possible that the ${ }^{99} \mathrm{Mo} /{ }^{99 m} \mathrm{Tc}$ radiochemical processing units could be economically operated, since the additional operational and infrastructure costs would be minimized.

\section{ADVANTAGES OF THE PROPOSED MODEL}

Such a proposed production scenario would have several advantages that could improve the economics of the ${ }^{99} \mathrm{Mo} /{ }^{99 m} \mathrm{Tc}$ supply chain, since the concern about highly enriched uranium proliferation, waste generation, and disposal issues from the use of low enriched uranium would be avoided. The irradiation capacity of existing U.S. nuclear reactors would be used with no additional reactor facility investments, and the inherently difficult local production challenges required for direct cyclotron production of ${ }^{99 \mathrm{~m}} \mathrm{Tc}$ using enriched ${ }^{100}$ Mo targets would also be avoided. Also, it remains to be seen whether the combined use of medical cyclotrons for routine production of both ${ }^{18} \mathrm{~F}$ and ${ }^{99 \mathrm{~m}} \mathrm{Tc}$ will limit the available beam time required for PET tracer development. Such an effect would be expected to reduce the ability of these facilities to develop new agents and, in turn, might negatively impact patient care. The basic radiochemical processing concepts for ${ }^{99} \mathrm{Mo}$ from reactor production are simpler than for processing of cyclotron targets for ${ }^{99 \mathrm{~m}} \mathrm{Tc}$ production. Although cyclotron-irradiated ${ }^{100}$ Mo targets yield ${ }^{99 m} \mathrm{Tc}$ only once, reactor-irradiated ${ }^{98} \mathrm{Mo}$ targets provide ${ }^{99 \mathrm{~m}} \mathrm{Tc}$ available from continuous ingrowth over an extended period. Although not required for ${ }^{99} \mathrm{Mo}$ production from

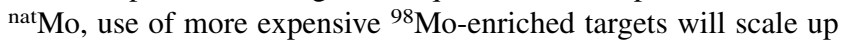
${ }^{99}$ Mo production by a factor of approximately 4 . With enriched ${ }^{98}$ Mo targets, the unused ${ }^{98}$ Mo target can be recovered for future use much as is the necessary enriched ${ }^{100}$ Mo recovery from cyclotron targets. There would be minimum expected loss $(<25 \%)$ of ${ }^{99} \mathrm{Mo}$ in the proposed strategy from parent radioactive decay, since ${ }^{99 \mathrm{~m}} \mathrm{Tc}$ can be extracted from the irradiated target within $24 \mathrm{~h}$ after EOB, whereas decay of about $70 \%-80 \%$ of ${ }^{99}$ Mo produced at EOB occurs before the initiation of alumina-based ${ }^{99} \mathrm{Mo} /{ }^{99 \mathrm{~m}} \mathrm{Tc}$ column generator use.

\section{CONCLUSION}

We have suggested a model for enhancing the availability of ${ }^{99 \mathrm{~m}} \mathrm{Tc}$ by having a diversified chain of radiochemical processing laboratories for processing low-specific-activity ${ }^{99} \mathrm{Mo}$. The model can work with the cooperation of a couple of existing U.S. reactors and with far lower investment than what is anticipated for evolving alternative models. We suggest the timeliness of a serious effort on the part of the nuclear medicine community, reactor facilities, commercial radiopharmaceutical entities, and policy makers to discuss the merit of the proposed model and implement the same to enhance the availability of ${ }^{99 \mathrm{~m}} \mathrm{Tc}$ and to address proliferation issues.

\section{DISCLOSURE}

The costs of publication of this article were defrayed in part by the payment of page charges. Therefore, and solely to indicate this fact, this article is hereby marked "advertisement" in accordance with 18 USC section 1734 . No potential conflict of interest relevant to this article was reported.

\section{REFERENCES}

1. Pillai MRA, Dash A, Knapp FF. Sustained availability of ${ }^{99 m T c: ~ p o s s i b l e ~ p a t h s ~}$ forward. J Nucl Med. 2013;54:313-323.

2. Non-HEU production technologies for molybdenum- 99 and technetium- $99 \mathrm{~m}$. 2013. International Atomic Energy Agency website. http://www-pub.iaea.org/ MTCD/Publications/PDF/Pub1589_web.pdf. Published 2013. Accessed December 8,2014

3. Cutler CS, Schwarz SW. Diversification in the supply chain of ${ }^{99}$ Mo ensures a future for ${ }^{99 \mathrm{~m} T \mathrm{Tc} .}$ J Nucl Med. 2014;55:1208-1213.

4. Dick D. Diversification of ${ }^{99} \mathrm{Mo} /{ }^{99 m}$ Tc supply. J Nucl Med. 2014;55:875-876.

5. Bénard F, Buckley KR, Ruth TJ, et al. Implementation of multi-curie production of ${ }^{99 \mathrm{~m}} \mathrm{Tc}$ by conventional medical cyclotrons. J Nucl Med. 2014;55:1017-1022.

6. Pillai MRA, Knapp FF Jr. Overcoming technetium-99m shortage: are options being overlooked? J Nucl Med. 2011;52(2):15N-16N, 28N.

7. Pillai MRA, Knapp FF Jr. Molybdenum-99 production from reactor irradiation of molybdenum targets: a viable strategy for enhanced availability of technetium99m. Q J Nucl Med Mol Imaging. 2012;56:385-399.

8. Dash A, Knapp FF, Pillai MRA. ${ }^{99} \mathrm{Mo} /{ }^{99 \mathrm{~m}} \mathrm{Tc}$ separation: an assessment of technology options. Nucl Med Biol. 2013;40:167-176.

9. Chattopadhyay S, Barua L, Das SS, et al. Pharmaceutical grade sodium [ ${ }^{99 \mathrm{~m}} \mathrm{Tc}$ ] pertechnetate from low specific activity ${ }^{99} \mathrm{Mo}$ using an automated ${ }^{99} \mathrm{Mo} /{ }^{99 m} \mathrm{Tc}-$ TCM-autosolex generator. J Radioanal Nucl Chem. 2014;302:1053-1068.

10. TechneGen. LegalForce Trademarkia website. http://www.trademarkia.com/ technegen-85420367.html. Accessed December 8, 2014. 